
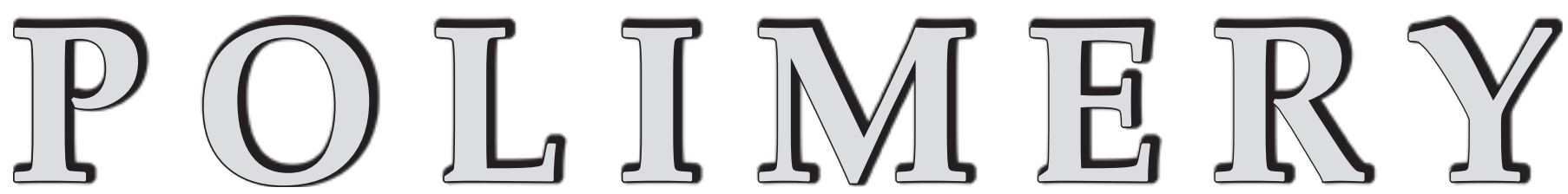

\title{
Pineapple leaf fibers as a reinforcement of biocomposites - an overview
}

\author{
Rahmah Mohamed ${ }^{1), *)}$ (ORCID ID: 0000-0001-9538-2555), Norsuriati Muhmad Hapizi ${ }^{1)}$ (0000-0002-9252-3057), \\ Mohd Nurrazi Norizan ${ }^{2)}$ (0000-0001-7697-0511), Nur Khairunnisa ${ }^{1)}$ (0000-0002-5893-8654)
}

DOI: dx.doi.org/10.14314/polimery.2021.11.1

\begin{abstract}
Based on 87 references, a literature review was presented on PLA reinforced with pineapple leaf fibers (PALF). The properties of PALF were compared with those of other natural fibers. Mechanical properties of PLA composites and factors influencing them, such as filler content, adhesion at the interface between polymer fiber and matrix, as well as fiber length and their modification were discussed. Potential applications of PLA/PALF composites were also presented.
\end{abstract}

Keywords: PLA, composites, pineapple leaf fibers (PALF), mechanical properties.

\section{Włókna z liści ananasa jako wzmocnienie biokompozytów - przegląd literatury}

Streszczenie: Na podstawie 87 pozycji literaturowych przedstawiono przegląd literatury dotyczący PLA wzmocnionego włóknami pozyskanymi z liści ananasa (PALF). Właściwości PALF porównano z właściwościami innych włókien naturalnych. Omówiono właściwości mechaniczne kompozytów PLA oraz czynniki na nie wpływające, takie jak zawartość napełniacza, adhezja na granicy faz włókno-osnowa polimerowa oraz długość włókna i jego modyfikacja. Przedstawiono również potencjalne zastosowania kompozytów PLA/PALF.

Słowa kluczowe: PLA, kompozyty, włókna pozyskane z liści ananasa (PALF), właściwości mechaniczne.

Composites based on biodegradable polymers are considered to be an alternative to conventional fossil polymers because it is expected to reduce carbon emissions and gradually replace materials that obtained from fossil fuels. Biocomposites have attracted attention because of

\footnotetext{
1) Universiti Teknologi MARA (UiTM), Faculty of Applied Science, Green Polymer Research Group, 40450 Shah Alam, Selangor, Malaysia.

2) Universiti Pertahanan Nasional Malaysia (UPNM), Centre for Defence Foundation Studies, Kem Perdana Sungai Besi, Kuala Lumpur 57000, Malaysia.

*) Author for correspondence: rahmahmd@uitm.edu.my
}

their properties, light weight and low cost [1]. They are obtained from a biopolymer matrix resin and a reinforcement of natural fibers. Poly(lactic acid) (PLA) is an interesting biopolymer due to its unique mechanical and physical properties, renewability, availability, biocompatibility [2] and biodegradability [3]. However, the main limitations of PLA are brittleness, water resistance and low impact strength. Using low cost natural fibers as a reinforcement may be a solution. The development of biocomposites provides an alternative source to maintain ecological and economic sustainable development by reducing the use of fossil raw materials and the amount of waste it produces. 
Natural fibers have many advantages compared to synthetic fibers such as abundance, renewability, cost effectiveness, low weight, biodegradability, high strength and stiffness $[4,5]$. However, the shortcomings of natural fibers such as moisture uptake, quality changes, and low thermal stability make them difficult to use in certain applications [4]. Moreover, the main disadvantages of natural fibers are their hydrophilic nature, poor fibermatrix interfacial adhesion and poor thermal stability [5]. However, this can be overcome by chemical treatment or the use of a compatibilizer that will improve the adhesion between the fibers and the polymer matrix.

In Malaysia, one of the most potential natural fibers that have recently attracted researchers are the fibers derived from pineapple leaf (PALF) [1]. PALF were chosen due to the abundant availability, low cost, good thermal and acoustic insulation, excellent tensile strength and high toughness. Moreover, PALF possess highest percentage of cellulose content and low microfibrillar angle which is chief responsible factor attributed to increased tensile properties [6]. Recently, studies have been carried out to investigate the mechanical properties of PLA/PALF by considering the mechanical characterization such as fiber loading, fiber length, chemical treatment and environmental effect.

\section{PLA REINFORCED WITH NATURAL FIBERS}

Today most of the polymers or product are produced from non-renewable resources such as petroleum. In this regard, PLA is the most extensively researched and utilized biodegradable and renewable aliphatic polyester [5]. PLA has a proven potential to replace conventional petrochemical-based polymers for industrial applications [7]. PLA is a leading degradable thermoplastic polymer with excellent mechanical properties which produce from natural resources of corn to lactic acid and subsequent chemical polymerization made by fermentation process [8]. PLA can be obtained in different ways. Firstly, it is a direct polycondensation reaction, and it usually produces a low molecular weight polymer, which can then be converted into a higher molecular weight polymer by adding a chain coupling agent. Secondly, poly(lactic acid) can be synthesized by ring-opening polymerization (ROP), because PLA is first produced by the formation of lactide monomer, and then the formed lactide usually uses metal alkoxide as a catalyst for ROP. ROP is usually used to produce high molecular weight PLA, where PLA is obtained by using catalysts and monomers in a vacuum environment. By controlling the temperature and time, as well as the type of catalyst used and its concentration in the process, the proportion and sequence of $\mathrm{D}$ and LLA units in the final polymer can be controlled $[3,9,10]$. Thirdly, azeotropic dehydrative condensation, while introducing organic solvents into the reaction mixture to promote the removal of water, thereby producing higher molecular weight products [11]. Currently, the first two methods are the most commonly used technologies in PLA industrial production. Ring-opening polymerization is dominant as the preferred process for industrial PLA production because of its short time consumption and high molecular weight of the final product, which makes it the most widespread and feasible method for producing PLA. High temperature and low pressure must be used to achieve high molecular weight of polymer [11, 12].

PLA has numerous advantages such as good stiffness, strength and toughness as well as low permeability performance against transfer of several gases such as water vapor and methane, and energy saving (compared to petroleum-based polymers, the energy required for the production of PLA is reduced by $25-55 \%$, and it is estimated that this proportion can be further reduced to less than $10 \%$ in the future) [11-13]. Lower energy use makes the production of PLA also having potential advantages in terms of cost and it degrades in a short period of time compared with petroleum polymers. PLA needs about two years and petroleum polymer needs an average of 8 years to degrade [14]. Compared to other biopolymers, PLA is also biocompatible, has a good printability and is easy to produce [7]. However, PLA still has a number of drawback that limit its application such as its inherent brittleness. PLA is a very brittle material with less than $10 \%$ elongation at break [7]. Although its tensile strength and elastic modulus are comparable to poly(ethylene terephthalate) (PET) [15], the poor toughness limits its use in the applications that need plastic deformation at higher stress levels (e.g., screws and fracture fixation plates) [13]. Second limitation of PLA is slow degradation rate. PLA degrades by hydrolysis of the ester groups backbone chain. The rate of degradation depends on the PLA crystallinity, molecular weight and its distribution, morphology, rate of water diffusion in the polymer and content of stereoisomers [16]. The rate of degradation is generally considered an important selection criterion for biomedical applications [17]. The slow degradation rate leads to a long in vivo life time, which could be up to years in some cases (mostly 3-5years) [13]. The slow degradation rate is a serious problem with respect to disposal of consumer commodities as well [18], and hydrophobicity as major drawbacks. PLA is relatively hydrophobic, and its static contact angle with water is about $80^{\circ} \mathrm{C}$. This leads to

T a b l e 1. Mechanical properties of PLA (Ingeo Biopolymer $3001 \mathrm{D}$, Nature Works)

\begin{tabular}{l|c}
\multicolumn{1}{c|}{ Mechanical properties } & Value \\
\hline Tensile strength at yield, MPa & 62 \\
Elongation at break, \% & 3.5 \\
Notch Izod impact strength, J/m & 16 \\
Flexural strength, MPa & 108 \\
Flexural modulus, MPa & 3600 \\
Heat distortion temperature, ${ }^{\circ} \mathrm{C}$ & 55 \\
\hline
\end{tabular}


T a b l e 2. PLA composites applications

\begin{tabular}{|c|c|c|}
\hline Branch & Applications & Ref. \\
\hline Domestic & $\begin{array}{l}\text { Plates and saucers, cups, cutlery, fruit juices, fresh water, and sports drinks bottles, cold drink cups, } \\
\text { transparent food containers, foodware, dairy containers, jelly and jam containers, and edible oils con- } \\
\text { tainers }\end{array}$ & \multirow{4}{*}{ [22] } \\
\hline Medicine & Medical devices such as plates, rods, pins, and screws & \\
\hline Packaging & $\begin{array}{c}\text { Vegetable bags, candy twist wrap, lidding film, blister packaging, window envelope film, label film, } \\
\text { shrink wrap material, and other packaging applications }\end{array}$ & \\
\hline 3D printing & $\begin{array}{l}\text { 3D filaments, lost PLA casting for molten metal, and other 3D printing medical device prototypes } \\
\text { (both biodegradable and permanent) }\end{array}$ & \\
\hline Textile & Household and industrial wipes, diapers, hygiene products, and disposable clothing & [23] \\
\hline Electronics & Programmable logic array (device used to implement combinational logic circuits) & \\
\hline Transportation & $\begin{array}{l}\text { Interior parts of cars such as carpet mats, canvas roofs, engine covers and impact shields, and extends } \\
\text { to exterior components including doors and instrument panels. }\end{array}$ & [24] \\
\hline Agriculture & Mulching films and packaging & \\
\hline
\end{tabular}

low cell affinity and in some cases, may cause an inflammatory response in direct contact with biological fluids of the living host [19]. Fortunately, the brittle nature of PLA can be improved by adding plasticizers that will increase the elongation at break [20]. Nevertheless, the addition of plasticizer will reduce the mechanical properties of PLA. In order to overcome these disadvantages, extensive research has been carried out to reinforce PLA with natural fibers. The mechanical properties of PLA are presented in Table 1 [21].

The increasing usage of petroleum-based polymer has led to environmental pollution and biopolymers are regarded as new generation of polymers that are still in development phase to produce environmental friendly product. There are seven main applications of PLA like domestic, medical, packaging, 3D printing [22], tex- tile, electronics, transportation and agricultural [23, 24]. Table 2 shows the applications of PLA composites by industrial branches.

\section{NATURAL FIBERS}

Until the early mid-20th century, natural fibers were used to reinforce the matrix. Since 1950, there has been a growing demand for stronger, stiffer, and lighter composites in the aerospace, transportation, and construction sectors. This has led to the introduction of high performance fibers for reinforcement [25]. The use of natural fibers as reinforcing materials for polymer matrix composites instead of synthetic fibers has attracted growing attention, mainly because they can be obtained from renewable natural resources, have satisfactory high spe-

T a b l e 3. Properties of natural and synthetic fibers

\begin{tabular}{l|c|c|c|c}
\hline \multicolumn{1}{c|}{ Fiber } & Density, g/cm & Tensile strength, MPa & Young's modulus, GPa & Elongation at break, \% \\
\hline Abaca & 1.50 & $430-980$ & $31.1-34$ & 3 \\
Bagasse & 1.20 & $20-290$ & $20-34$ & 1 \\
Banana & 1.35 & 355 & 34 & 5 \\
Coir & 1.25 & $175-220$ & $4-6$ & $15-30$ \\
Cotton & $1.50-1.60$ & $287-597$ & $6-12$ & $3-10$ \\
Flax & $1.40-1.50$ & $800-1500$ & $60-80$ & $2.7-3.2$ \\
Hemp & 1.48 & $550-900$ & $38-70$ & $2-4$ \\
Jute & $1.30-1.46$ & $393-800$ & $13-27$ & $1.5-1.8$ \\
Kenaf & $1.50-1.60$ & $350-930$ & $40-53$ & $3-7$ \\
Oil Palm & $0.70-1.55$ & 248 & 3 & 3 \\
PALF & 1.50 & $170-1627$ & 82 & $1-3$ \\
Ramie & $1.50-1.60$ & $400-938$ & $61-128$ & $2-4$ \\
Sisal & $1.33-1.50$ & $468-700$ & $9-38$ & $2-14$ \\
Pineapple & 1.56 & 170 & 62 & - \\
Sun hemp & 1.07 & 389 & 35 & 2 \\
E-glass & 2.55 & 3400 & 73 & 3 \\
Kevlar & 1.44 & 3000 & $240-425$ & $3-4$ \\
Carbon & 1.78 & $3400-4800$ & & $1-2$ \\
\hline
\end{tabular}


cific resistance and modulus, light weight, low cost and biodegradability. The biodegradability of natural plant fibers can preserve a healthy ecosystem, while low cost and good performance of these fibers can meet the economic benefits of the industry [26]. The main advantage of this natural fiber is that it can be decomposed naturally, so it will not pollute the environment at the end of its use. This natural fiber has many other advantages such as recyclability, reusability, environmental friendliness, renewability, and abundance [11, 12]. Compared to glass fibers, natural fibers have lower density (1.2-1.6 $\left.\mathrm{g} / \mathrm{cm}^{3}\right)$, which is lower than glass fiber $\left(2.4 \mathrm{~g} / \mathrm{cm}^{3}\right)$, good damping properties, less abrasive damage to equipment, and high health and safety standards (i.e., low skin irritation) [27].

However, moisture uptake, quality variations and low thermal stability are considered limitations of natural fibers [4]. Increasing research effort have been made in recent years to enhance the utilization of plant-based natural fibers, such as coconut coir, pineapple leaf fiber, kenaf, bamboo fiber, and so forth, due to environmental and sustainability concerns [3]. Many investigations have been made on the potential of the natural fibers as reinforcements for composites and in several cases it occurred that the natural fiber composites had good stiffness [4]. Many types of natural fibers have been used to reinforce PLA and produce lightweight composites as shown in Table 3. Examples include straw, hemp, kenaf, hollow palm oil fruit fiber and pineapple leaf fiber [13-18].

Natural fibers are extracted from different plants and animals (chicken feathers, hair, etc.). Plant fibers are composed of cellulose, lignin, hemicellulose, and wax as shown in Table 4.

Different natural fibers show different percentage of chemical composition. Reinforcing efficiency of natural fibers depends on the nature of cellulose and its crystallinity. Cellulose is hydrophilic, and its presence affects the interfacial bonds between polymer matrices and fibers because the matrix is hydrophobic. The chemical treatment of natural fibers is one of the ways to optimize the interaction between the fibers and the polymer matrix. Because it reduces the $\mathrm{OH}$ functional groups present on the fiber surface, it also increases the surface roughness, thus improving the interface interaction between the matrix and the fiber.

There are certain natural fibers that have increasing demands of use such as pineapple leaf fibers (PALF), kenaf, oil palm etc. PALF received extensive research due to the fact that PALF contributed with excellent mechanical properties compared to other natural fibers. PALF is multi-cellular and lignocellulosic. PALF consists about $81 \%$ of cellulose. Besides that, other primary chemical

T a b l e 4. Chemical composition of selected natural fibers

\begin{tabular}{|c|c|c|c|c|}
\hline Fiber & Cellulose, wt $\%$ & Hemicellulose, wt $\%$ & Lignin, wt $\%$ & Waxes, $\mathrm{wt}^{\mathrm{o}} \%$ \\
\hline Abaca & $56-63$ & $20-25$ & $7-9$ & 3 \\
\hline Alfa & 45 & 39 & 15 & 2 \\
\hline Bagasse & 55 & 17 & 25 & - \\
\hline Bamboo & $26-43$ & 30 & $21-31$ & - \\
\hline Banana & $63-64$ & 19 & 5 & - \\
\hline Coir & $32-43$ & $0.2-0.3$ & $40-45$ & - \\
\hline Cotton & $85-90$ & 6 & - & 0.6 \\
\hline Caraua & 74 & 10 & 8 & - \\
\hline Flax & 71 & $19-21$ & 2 & 1.5 \\
\hline Hemp & 68 & 15 & 10 & 0.8 \\
\hline Henequen & 60 & 28 & 8 & 0.5 \\
\hline Isora & 74 & - & 23 & 1.1 \\
\hline Jute & $61-71$ & $14-20$ & $12-13$ & 0.5 \\
\hline Kenaf & 72 & 20 & 9 & - \\
\hline Kudzu & 33 & 12 & 14 & - \\
\hline Nettle & 86 & 10 & - & 4 \\
\hline Oil Palm & 65 & - & 29 & - \\
\hline Piassava & 29 & 26 & 45 & - \\
\hline Pineapple & 81 & - & 13 & - \\
\hline Ramie & $69-76$ & $13-16$ & $0.6-0.7$ & 0.3 \\
\hline Sisal & 65 & 12 & 10 & 2 \\
\hline Sponge gourd & 63 & 19 & 11 & 3 \\
\hline Straw (wheat) & $38-45$ & $15-31$ & $12-20$ & - \\
\hline Sun hemp & $41-48$ & $8-13$ & 23 & - \\
\hline
\end{tabular}


constituents of PALF are lignin (12.7\%) and ash (1.1\%) $[28,29]$. The high cellulose content and low microfibrillar angle associated with these fibers lead to the excellent mechanical properties of PALF [30]. Lately oil palm fiber (OPF) had received attention as Malaysia and tropical countries had produced abundance of oil palm wastes. This oil palm fruit bunch fiber (EFB) has high cellulose content as shown in Table 4 and has potential as natural fiber resource, but its applications account for a small percentage (20-23\%) of the total biomass production [31]. Among the several types of natural fibers, kenaf fiber also has gained considerable attention and has been largely utilized over the last two years. The main reason are rapid growing abilities of kenaf plant which enables to produce a great volume of raw materials in a short period of time and consequent low price. Natural fibers such as kenaf fiber are far cheaper when compared with carbon fiber and glass fiber [32]. The price of kenaf fiber per $\mathrm{kg}$ is 0.53 US\$ while glass fiber and carbon fiber are 3.25 US\$ and 500 US\$ per kg respectively [32]. It was observed that natural fiber sources were cost-effective alternatives.

\section{PINEAPPLE LEAF FIBER}

Industrial interest in the use of pineapple leaf fiber (PALF) as an alternative resource, especially as a reinforcing material in polymeric composites has increased significantly. PALF obtained from pineapple plant (Ananas comosus), from Bromeliaceae family is selected as a natural fiber due to its higher cellulose content and the good mechanical properties [33]. Pineapple is one of the most important tropical fruits in Malaysia and PALF is a waste of pineapple cultivation. Therefore, PALF can be obtained from pineapple leaves by scrapping, removing or peeling them, and can be used for significant purposes at no additional cost [30]. PALF is a white, creamy, shiny and silky fiber that is 10 times rougher than cotton which can be seen in Figure 1 [34].

In addition, these fibers easily retain dyes. PALF is a multicellular lignocellulosic fiber that contains polysaccharides, a large amount of lignin and some mineral

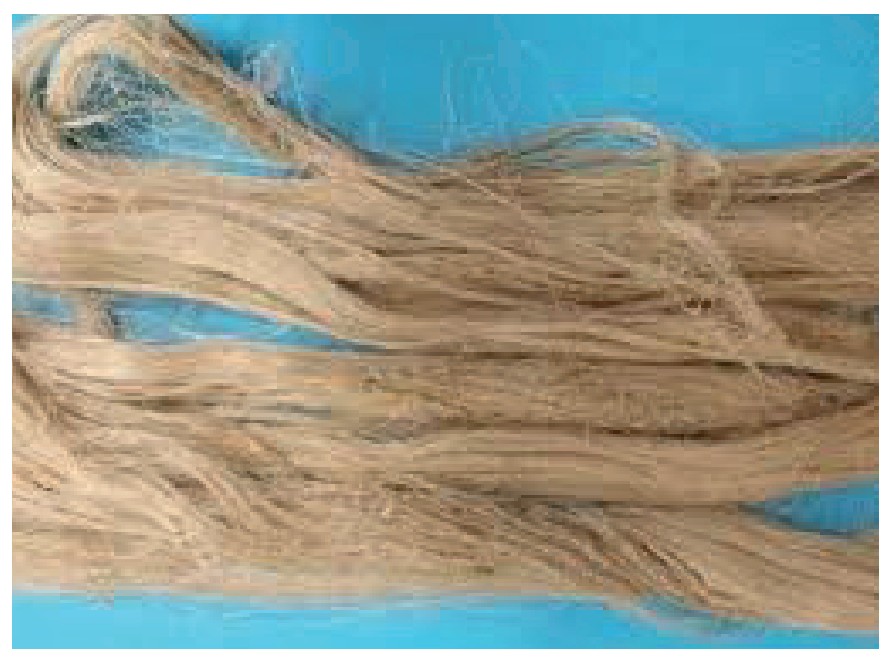

Fig. 1. Fibers from pineapple leaf

chemical substances, such as oils, waxes, pectins, uric acid, anhydrides, pentosanes, pigments, inorganic substances, etc. PALF contains cellulose (70-82\%), and the fiber structure is the same as cotton (about 83\%) [6]. PALF has a low content of hemicellulose $(12.3 \%)$ and lignin $(3.5 \%)[28,30]$. Table 5 shows the summarized chemical composition of PALF [34]. In the whole range, pineapple leaf fiber is the most compatible natural fiber resource and has a strong chemical composition.

PALF has higher mechanical resistance than jute when used to make spun yarn [9].The fiber chemical composition directly affects performance of fibers. PALF is a vital natural fiber with a high specific strength (126-1627 MPa), stiffness (4.2-8.2 GPa) [13], flexural and torsional rigidity as good as jute fibers [33]. The superiority of PALFs mechanical properties is related with the high content of alpha-cellulose and low microfibrillar angle $\left(8-15^{\circ}\right)$ [34]. In view of these exclusive properties of PALF, the industries can use it as an outstanding alternative raw material for the purpose of reinforcing composite matrixes [13]. However, PALF has a lower degree of compatibility with hydrophobic polymers due to its hygroscopic nature. The presence of natural waxy material on the surface of the fiber layer provides a low surface tension which does not allow a strong bond to the polymer matrix. In addition to

T a b l e 5. PALF chemical composition

\begin{tabular}{|c|c|c|c|c|c|c|c|}
\hline $\begin{array}{c}\text { Cellulose } \\
\text { wt } \%\end{array}$ & $\begin{array}{c}\text { Hemicellulose } \\
\text { wt } \%\end{array}$ & $\begin{array}{c}\text { Hollocellulose } \\
\text { wt } \%\end{array}$ & $\begin{array}{l}\text { Lignin } \\
\text { wt } \%\end{array}$ & $\begin{array}{c}\text { Pectin } \\
\text { wt } \%\end{array}$ & $\begin{array}{c}\text { Fat and wax } \\
\text { wt } \%\end{array}$ & $\begin{array}{l}\text { Ash } \\
\text { wt } \%\end{array}$ & Ref. \\
\hline 69.5 & - & - & 4.4 & 1.2 & 4.2 & 2.7 & [35] \\
\hline 68.5 & 18.8 & - & 6 & 1.1 & 3.2 & 0.9 & [36] \\
\hline $70-82$ & - & - & $5-12.7$ & - & - & - & [37] \\
\hline $70-82$ & 18 & 80.5 & $5-12$ & - & - & $0.7-0.9$ & [38] \\
\hline 73.4 & - & - & 10.5 & - & - & 2 & [39] \\
\hline 81 & - & - & 12.7 & - & - & - & [40] \\
\hline 80 & - & - & 12 & - & - & $0.1-1$ & [41] \\
\hline $69-76$ & - & - & $14.5-15.4$ & - & - & 1.2 & [42] \\
\hline 81 & - & $82.3-85.5$ & 12.7 & - & - & - & [43] \\
\hline
\end{tabular}


T a b l e 6. PALF mechanical and physical properties [34]

\begin{tabular}{|c|c|c|c|c|c|c|c|c|c|}
\hline $\begin{array}{l}\text { Cell length } \\
\text { mm }\end{array}$ & $\begin{array}{c}\text { Diameter } \\
\mu \mathrm{m}\end{array}$ & $\begin{array}{c}\text { Density } \\
\mathrm{g} / \mathrm{cm}^{3}\end{array}$ & $\begin{array}{c}\text { Elongation } \\
\text { at break } \\
\%\end{array}$ & $\begin{array}{l}\text { Micro-fibrillar } \\
\text { angle }\end{array}$ & $\begin{array}{c}\text { Moisture } \\
\text { content } \\
\%\end{array}$ & $\begin{array}{c}\text { Tensile } \\
\text { strength } \\
\mathrm{MPa}\end{array}$ & $\begin{array}{c}\text { Technical } \\
\text { length } \\
\mathrm{mm}\end{array}$ & $\begin{array}{c}\text { Young's } \\
\text { modulus } \\
\text { GPa }\end{array}$ & Ref. \\
\hline- & $5-30$ & 1.44 & 1.6 & 12 & - & 170 & - & 6.3 & [46] \\
\hline - & - & 1.36 & 3.4 & - & - & 445 & - & 13.2 & [47] \\
\hline- & $20-80$ & - & 1.6 & 14 & 11.8 & $413-1627$ & - & $34.5-82.5$ & [37] \\
\hline $3-9$ & - & - & $0.8-1.6$ & - & $10-13$ & - & - & - & [38] \\
\hline- & - & 1.07 & 2.2 & - & - & 127 & - & 4.4 & [48] \\
\hline - & $50 \pm 6$ & 1.53 & $3-4$ & 14 & 13.5 & 413 & - & 4.2 & [40] \\
\hline 10 & $1.6-4.5$ & 1.44 & - & $8-15$ & - & - & $20-80$ & - & [41] \\
\hline - & $105-300$ & - & 1.4 & & - & 293 & - & 18.9 & [49] \\
\hline - & - & - & 2.4 & & - & $170-1627$ & - & $60-82$ & [50] \\
\hline
\end{tabular}

the pectin and waxy substances in plant fiber acting as a barrier to interlock with nonpolar polymer matrix, the presence of plenty hydroxyl groups hinders its operative reaction with the matrix. Therefore, the modification of the surface characteristics of plant fiber and hydrophobic polymer matrix is very important in order to formulate a reasonable composite with superior interfacial bonding and effective inherent stress transfer throughout the interface [44]. However the literature suggests a method to strengthen the fiber surface to make it ideal for good interfacial fiber-matrix bonding by introducing a suitable chemical treatment prior to fabricating the biocomposites samples [45]. Furthermore, these allow reduction in the hydrophilic nature of the natural fibers as well as removing the impurities within the fibers, resulting in an improvement in adhesion between the fiber and the matrix. Besides, there are a few other factors affecting the mechanical properties of PALF including fiber loading, fiber length, adhesion between fiber and matrix etc. There are recent studies that has been carried out by different researchers on mechanical and physical properties of PALF and factors affecting it as shown in Table 6.

a)

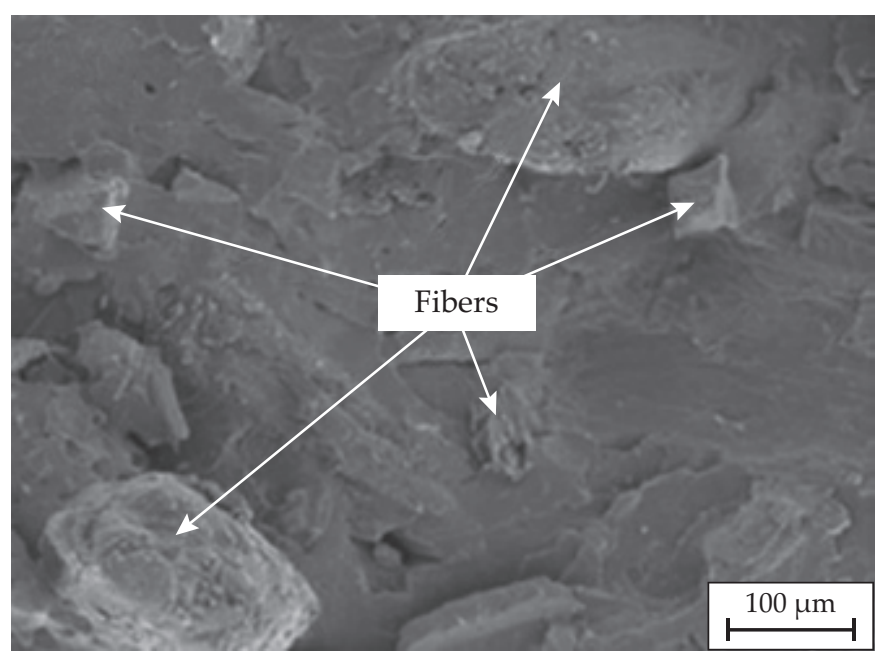

\section{FACTORS AFFECTING MECHANICAL PROPERTIES}

There are many factors which affect mechanical properties of composites filled with natural fibers [51]. The most important are the cellulose content of the used filler, as well as the fiber length, fiber load or fiber volume fraction, fiber aspect ratio, fiber orientation or adhesion between the fiber and the polymer matrix.

\section{Fiber loading}

It was reported that tensile strength and Young's modulus of oil palm fiber-reinforced natural rubber increase with increasing fibers content up to $30 \mathrm{wt}$ \%, and then decrease [52]. The improvement could be associated with the desirable strength of the individual oil palm fibers or perhaps due to even distribution of fibers within the matrix at $30 \mathrm{wt} \%$. Below $30 \mathrm{wt} \%$ there might be effect of fibers localization on the matrix leading to ineffectiveness in stress transfer between fibers and matrix. This could be the reason for the lower tensile strength and lower

b)

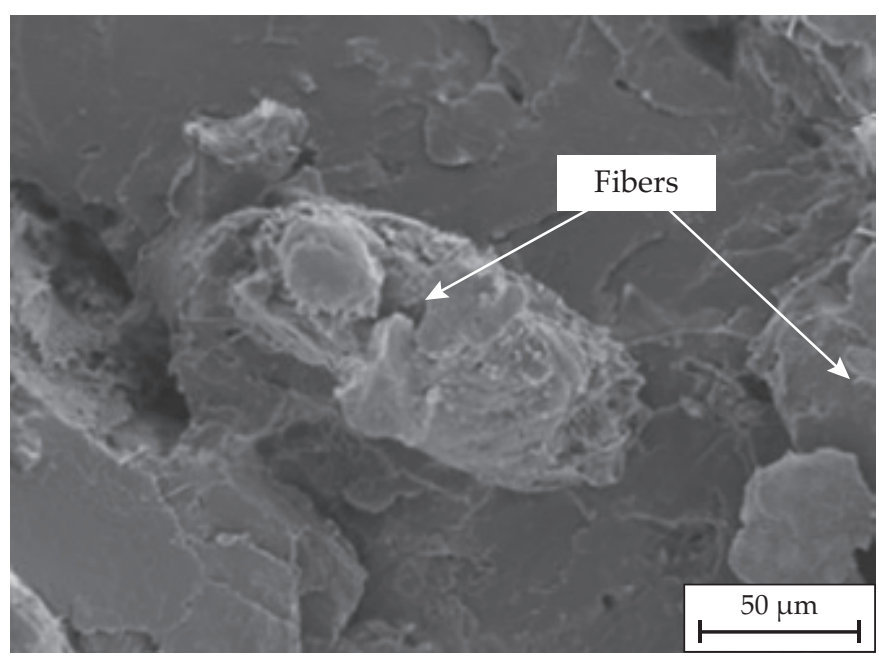

Fig. 2. SEM micrographs of PLA/WF (70/30) composite at scales of: a) $100 \mu \mathrm{m}$ and (b) $50 \mu \mathrm{m}$ 


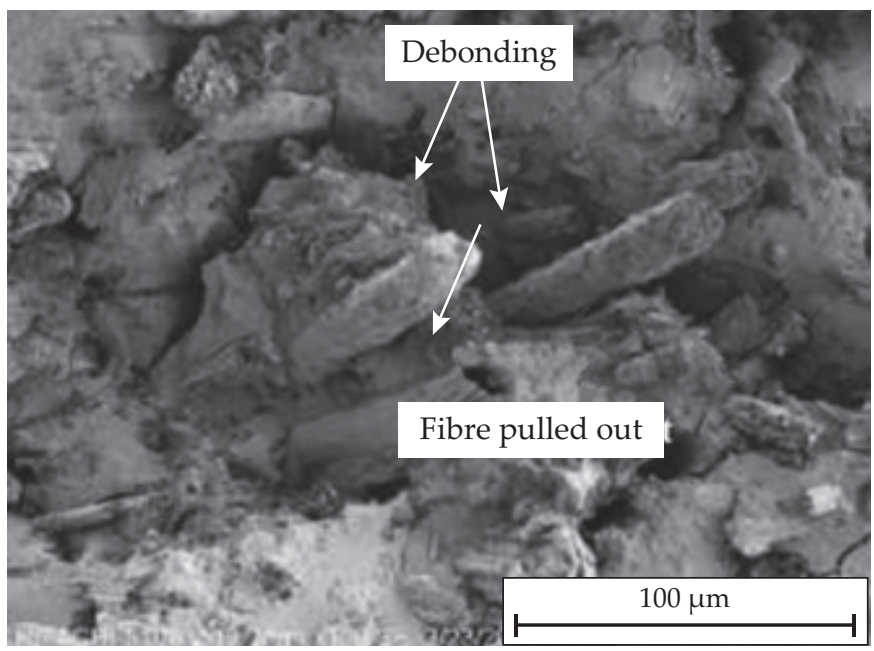

b)

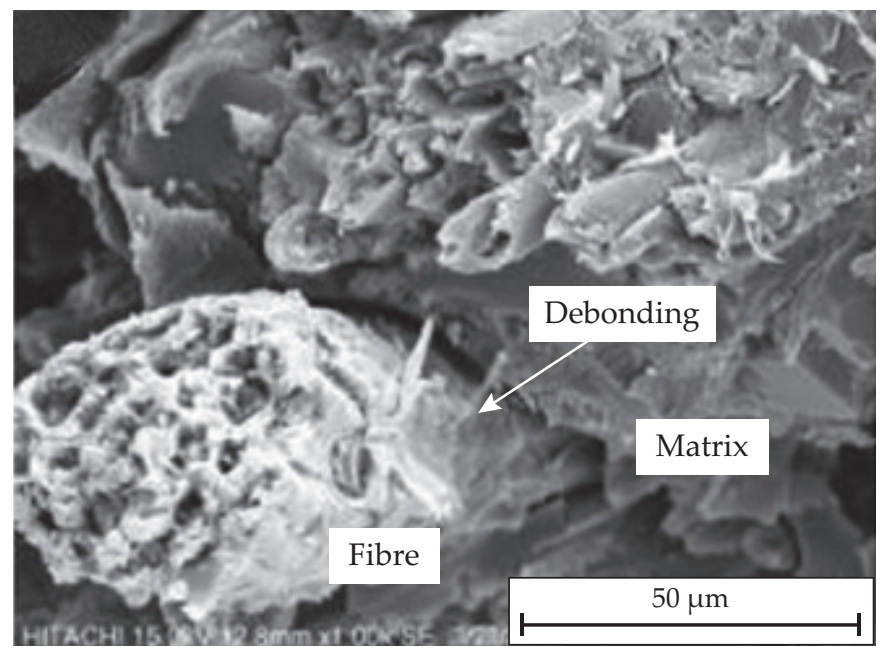

Fig. 3. SEM images of the composite reinforced with untreated fiber at scales of: a) $100 \mu \mathrm{m}$, b) $50 \mu \mathrm{m}$

a)

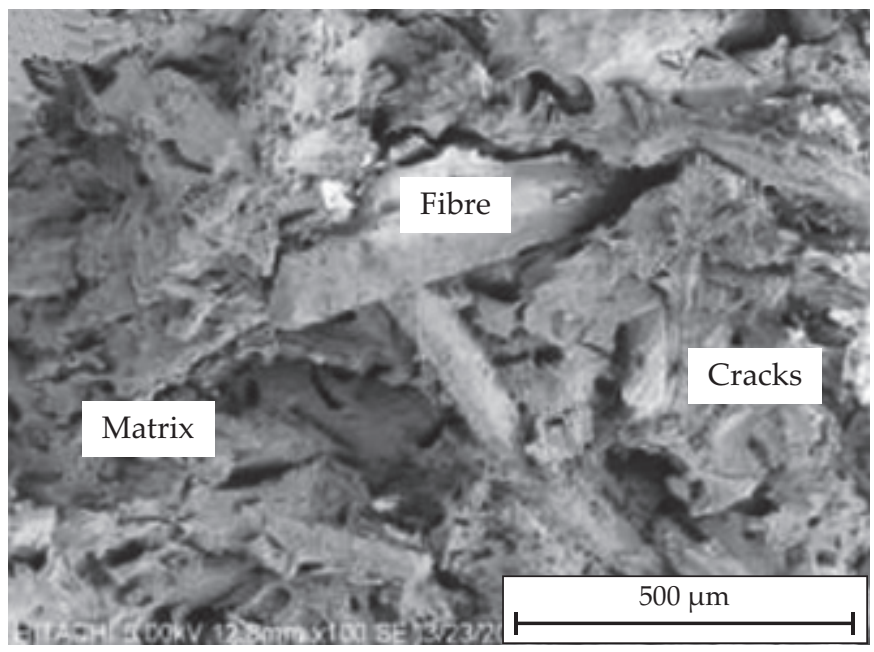

b)

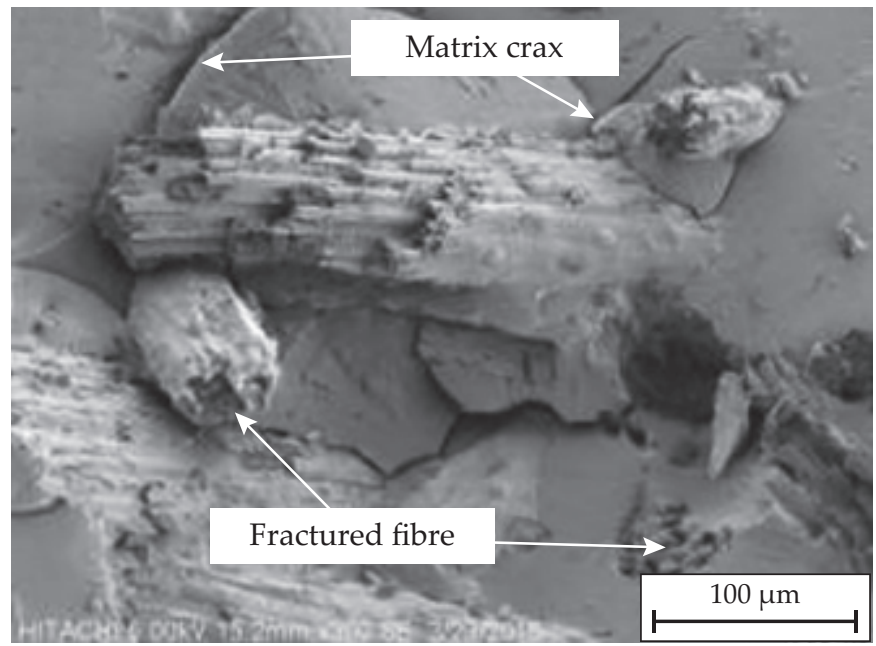

Fig. 4. SEM images of the composite reinforced with sea water treated fiber at scales of: a) $500 \mu \mathrm{m}, \mathrm{b}) 100 \mu \mathrm{m}$

a)

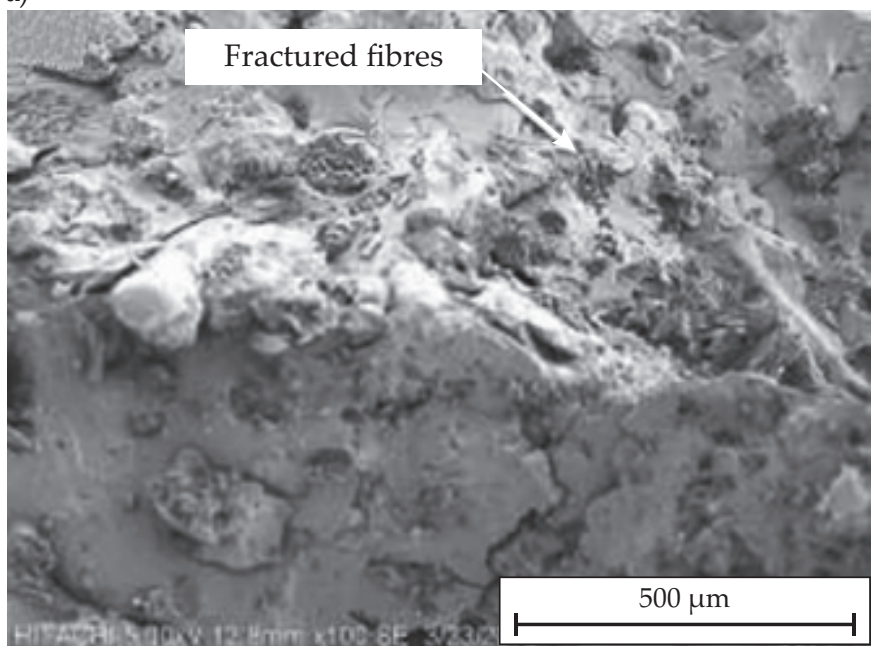

b)

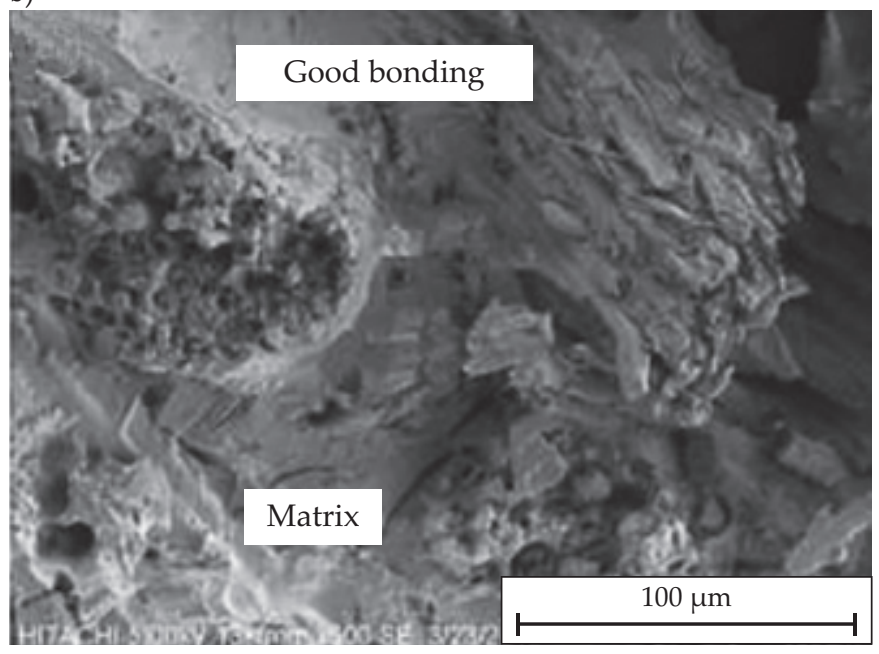

Fig. 5. SEM images of the composite reinforced with alkaline treated fiber at scales of: a) $500 \mu \mathrm{m}$, b) $100 \mu \mathrm{m}$ 
Young's modulus compared to a composite with $30 \mathrm{wt} \%$ fiber loading [52]. On the other hand, above $30 \mathrm{wt} \%$, the reduced tensile strength and Young's modulus could be due to uneven distribution of fiber within the composite. It had been pointed out that when composite materials are overloaded with excess of fiber, the fibers come too close to each other leading to their agglomeration. Agglomeration within the composite would then lead to excessive break in stress transfer between matrix and fiber and the consequence of this would be a reduction in tensile properties [53].

According to M. Huda et al. [54] the introduction of 20-30 wt\% wood fiber (WF) to PLA significantly improves its flexural properties. However, with a higher WF content, both the flexural strength and the modulus decrease. The large increase in the modulus when $30 \mathrm{wt} \%$ of wood fiber is added suggests an efficient stress transfer between the polymer and the fibers. The SEM micrographs presented in Figure 2 show that the wood fibers have been separated during the extrusion process and are well dispersed in the PLA matrix. Moreover, at higher magnification, good adhesion between the fibers and the matrix is visible (Figure 2b). It is also difficult to distinguish the WFs from the PLA matrix, and this may suggest that the fibers are coated, probably by the polymer, and that failure most commonly occurs in the matrix and not at the fiber surface. This also suggests that there is some kind of interfacial contact between the PLA matrix and WFs.

\section{Interfacial adhesion between fiber and matrix}

Bushra Rashid et al. [55] reported that phenolic composites reinforced with alkali treated $(0.5 \%$ sodium hydroxide) sugar palm fibers showed the highest flexural strength. The composites reinforced with sea water treated fibers had slightly lower flexural strength. The composites with untreated fibers showed the lowest flexural properties, which may indicate weak fiber-matrix interfacial adhesion. SEM studies confirmed poor interactions at the interface, as evidenced by the many pulledout fibers shown in Figure 3. This clearly indicated that the load transfer between the fibers and matrix was ineffective. Interestingly, both the sea water and alkaline treatments enhanced the flexural strength, which was attributed to strong adhesion between the fibers and matrix [55]. Furthermore, the increased flexural strength was good evidence that both of the treatments promoted better interfacial bonding and good wettability [45], which resulted in an effective stress transfer between the fiber and matrix [55]. Figures 4 and 5 show SEM images of composites filled with fibers treated with sea water or alkaline, respectively. Less pulled out fibers than broken ones can be seen. Moreover, no gaps or delamination between the fiber and the matrix were observed. Also, the fibers stayed firm in their position. These observations indicated the good interlocking of the fiber-matrix, which resulted in the better mechanical properties of the composites. The SEM observations were in accordance with the mechanical properties of the composites, proving that the treated fibers enhanced the behavior of the composites.

It is well known that the mechanical properties of composites are greatly influenced by the adhesion between the polymer matrix and the fibers [51]. It's because mechanical strength consists in effective stress transfer between filler and matrix and brittleness or toughness is dependent on adhesion. In natural fiber composites, the pretreatment of the fibers often showed an increase in mechanical properties due to the improved interface or adhesion of the fibers to the matrix. Chemical methods of the fiber pretreatment modify the surface, clean the fibers surface, reduce the moisture absorption process and increase the surface unevenness.

Some of the important industrial methods that are currently used to modify natural fibers in order to improve fiber-matrix interfaces in composites include: mercerization, acetylation, etherification, peroxide treatment, benzoylation, graft copolymerization, acrylation, maleic anhydride grafting, titanate treatment, permanganate, sodium chlorite treatment, plasma treatment, isocyanate treatment and the use of a coupling agent such as silane [56]. Although many of chemical treatments are available, most commonly alkaline treatment is used. The alkaline treatment removes the unwanted material like wax, lignin and oil substance from the fibers surface. It also increases the fiber surface roughness which develops the better interlocking ability of the fiber with matrix [57].The effectiveness of the composites reinforced with natural fibers consists in the fiber-polymer matrix interface and tendency to transfer stress from the matrix to the fibers. The main obstacle is the lack of perfect interfacial adhesion. Inherently high moisture absorption or poor resistance to moisture and low melting point lead to microcracking of the composite, which results in deterioration of mechanical properties and, as a result, less attractive applications of composites reinforced with natural fibers [58]. This problem can be solved by chemical modification of the filler. Islam et al. [59] described the effect of hemp fibers alkaline treatment on the nature of composite interfacial interactions. This treatment increased the fracture toughness of the composites by creating a strong bond between the fibers and the matrix, which reduced the pull-out of the fibers under load.

Mylsamy and Rajendran [60] found that alkaline treated agave fibers increased the mechanical strength of composites. This is caused by the dissolution of the hemicellulose and increased aspect ratio, which became the main reason for the increased interfacial adhesion between the fiber and matrix that correspondingly increased the strength. Srisuwan et al. [61] investigated epoxy composites with the addition of $\mathrm{NaOH}$ and silane treated woven sisal fiber. Improvement in flexural mechanical properties was observed in the composites. The silane compo- 
a)

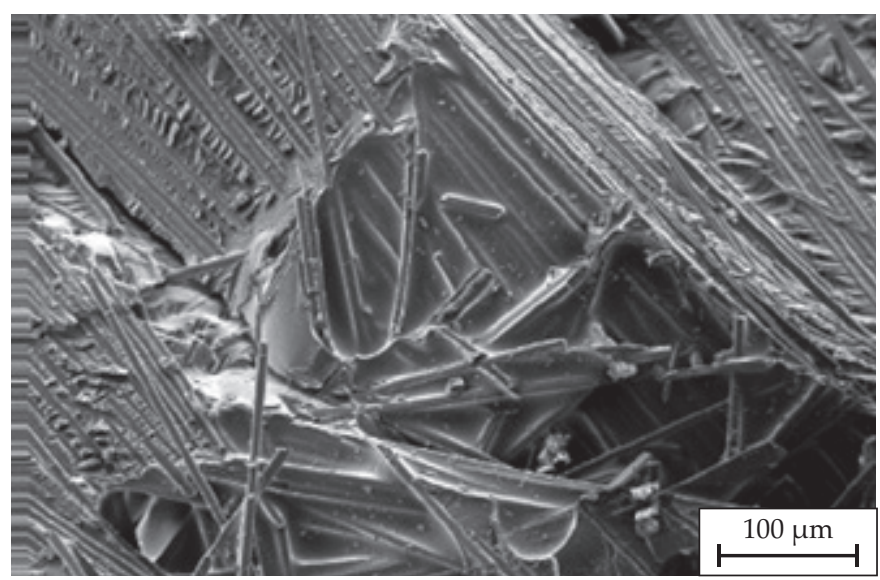

b)

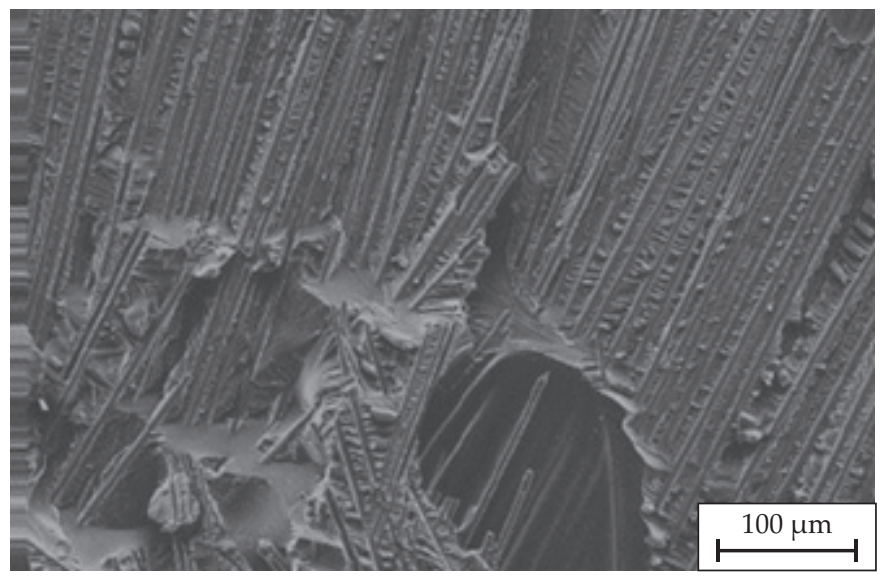

Fig. 6. SEM images of epoxy resin/carbon fiber (40/60) composites: a) $2 \mathrm{~mm}$ fiber, b) $4 \mathrm{~mm}$ fiber; all images were reported at scales of $100 \mu \mathrm{m}$

nents on the fibers surface increased the fibers bonding with the matrix and increased the flexural modulus of the composites. This is mainly due to removing the outer layer from the fiber surface and increasing the surface area for effective bonding.

\section{Fiber length}

Aji et al. [62] investigated the effect of fiber type (kenaf/ PALF), length and content on HDPE tensile properties. The increase in fiber length from 0.25 to $0.5 \mathrm{~mm}$ did not enhance the mechanical properties of HDPE. However, by treating the fibers, it is possible to increase the tensile strength through better interactions at the interface [63]. Addition of short carbon fiber $(7 \mathrm{~mm})$ significantly increased flexural strength of geopolymer composites [64]. Rezaei et al. [65] reported that longer carbon fiber improved the thermal stability and damping properties of polypropylene more than shorter. The effect of the fiber length $(2,4$ and $6 \mathrm{~mm})$ on mechanical properties of highly reinforced epoxy resin was studied by Capela et al. [66]. The composites showed a relatively small improvement in tensile strength and stiffness. However, stiffness increased by $25 \%$ as fiber length increased from 2 to $4 \mathrm{~mm}$, but tended to decrease as fiber length reached $6 \mathrm{~mm}$. The same tendency was observed for the tensile strength. Poor fibers dispersion and disorder were achieved for high fibers content composites, particularly for $6 \mathrm{~mm}$ long fibers. The storage modulus increased with increasing fiber length from 2 to $4 \mathrm{~mm}$, and still slightly increased as fiber length increased to $6 \mathrm{~mm}$ [66]. Figures 6 shows the fracture surface of epoxy composites with a fiber length of 2 and $4 \mathrm{~mm}$, respectively. In both cases, the dispersion of the fibers is insufficient and the exfoliation is poor, especially in the case of a $4 \mathrm{~mm}$ long fiber. SEM micrographs (Fig. 6) show voids, which indicates poor adhesion between the fiber and the polymer matrix. The predominant failure mechanism is the fiberresin decohesion.

\section{PLA/PALF COMPOSITES}

\section{The effect of fiber alkaline treatment}

Figure 7 shows the effect of untreated (PALFS) and alkaline-treated (PALFSNA) short fibers from pineapple leaf on flexural properties of PLA [46]. Obviously, the $\mathrm{NaOH}$ treatment improves the flexural properties of the composites, and the flexural strength and flexural modulus are increased by $220 \%$ and $46 \%$, respectively. It can also be concluded that the surface treatment increases fibers roughness, thus improving interfacial adhesion between the fibers and polymer matrix, consequently improving the mechanical properties of the composite [15].

Figure 8 shows SEM micrographs of PLA reinforced with untreated and alkaline-treated short PALF fibers after a flexural test. It is clear from Figure 8a that untreated fibers have a smooth surface, whereas, the treated fibers have a rough surface due to physical microstructural changes (Figure 8b). Improved adhesion between treated PALF fibers and PLA matrix is achieved due to elimination of impurities during the alkaline pre-treatment process of the fibers. The addition of sodium hydroxide enhances the adhesion between PLA and PALF interface

Flexural strength, $\mathrm{MPa}$

Flexural modulus, GPa

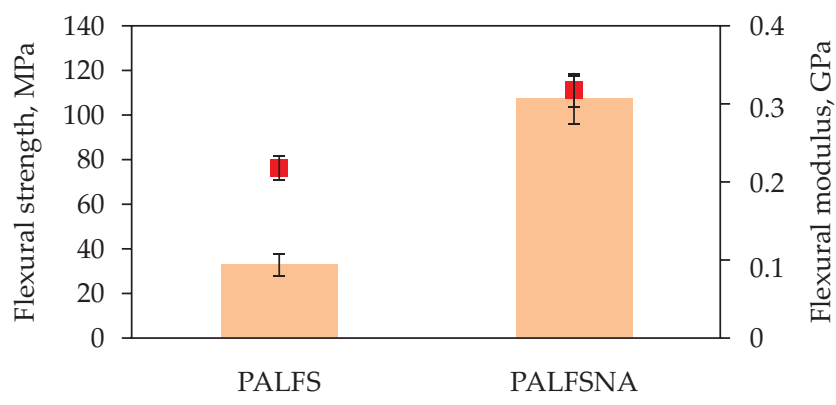

Fig. 7. The effect of untreated (PALFS) and alkaline-treated (PALFSNA) fibers on the flexural properties of PLA 


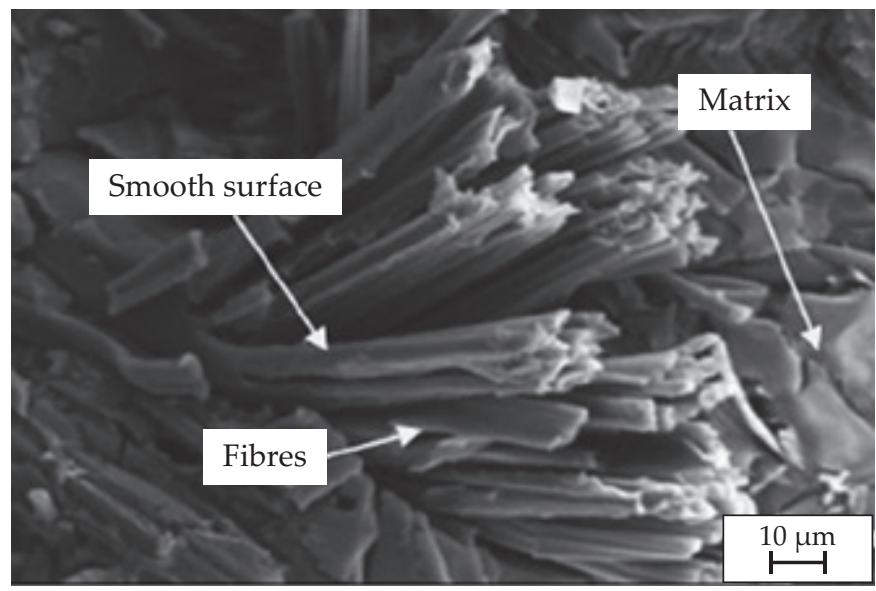

b)

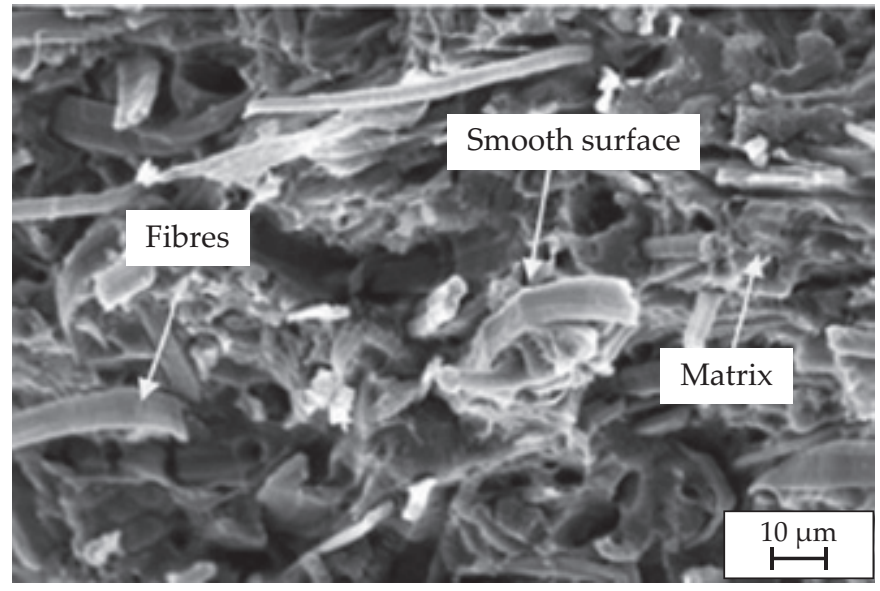

Fig. 8. SEM micrographs of PLA/PALF composites after flexural test: a) untreated PALF and b) treated PALF; all images were reported at scales of $10 \mu \mathrm{m}$

which results in better mechanical properties of the composites by increasing the fiber surface roughness.

Shibata et al. [67] reported that PALF increased the flexural modulus of PLA but decreased flexural strength. When PALF was treated with $\mathrm{NaOH}$, the flexural strength of the composites became higher than that of untreated. It can be explained by intrinsically increased fibers strength and their better wetting by the matrix. Moreover, Felix [68] suggested that partial or complete removal of amorphous fiber components, such as lignin or surface contamination, increased interactions at the interface, which resulted in better wettability of the fibers. The chemical modification of PALF fibers significantly affected PLA flexural properties due to the better adhesion at the interface [29].

Alkaline-treated short PALF fibers also improved mechanical properties of other polymers, including highimpact polystyrene (HIPS). Siregar et al. [69] investigated the effect of $\mathrm{NaOH}$ concentration (2 and $4 \mathrm{wt} \%$ ) used for the treatment of short PALF fibers on the tensile properties of HIPS. The tensile strength and tensile modulus of the HIPS/PALF composites increased as a function of $\mathrm{NaOH}$ concentration from 23 to $30 \mathrm{MPa}$ and from 825 to 1285 MPA, respectively. The observed improvement in the mechanical properties of the HIPS/PALF composite resulted from better wettability of the treated fibers and better interaction at the matrix-fiber interface [58].

\section{The effect of fiber length and content}

Fig. 9 shows the flexural properties of PLA reinforced with (i) untreated short PALF fibers (PALFS), (ii) alkaline-treated short PALF fibers (PALFSNA), (iii) untreated long PALF fibers (PALFLO) and (iv) alkaline-treated long PALF fibers (PALFLONA) [46]. Long fibers reinforced composites have higher strength and modulus whether the fibers are treated with alkaline or not. Furthermore, with the alkaline treatment of the fiber, the flexural properties of the composite are significantly improved. The maximum flexural strength of the long PALF fiber reinforced PLA is approximately $114 \mathrm{MPa}$, compared to the PLA reinforced with untreated PALF short fiber (34 MPa). In terms of stiffness, the flexural modulus of a long fiber reinforced PLA is about $5.70 \mathrm{GPa}$ while the flexural modulus of untreated short fiber reinforced PLA is only $0.22 \mathrm{GPa}$. These findings indicate that long fibers have better mechanical properties than short fibers. These results indicate a significant influence of the PALF fibers length on the mechanical properties of PLA. According to Lee et al. [70] randomly oriented short fibers show the lowest degree of dispersion in the polymer matrix.

Md Fadzullah et al. [71] reported that PLA reinforced with long PALF fibers $(100 \mu \mathrm{m})$ in the amount of $30 \mathrm{wt} \%$ showed significantly higher flexural strength (> 30\%) and modulus ( $>45 \%$ ) than reinforced with short PALF fibers $(30 \mu \mathrm{m})$ as shown in Table 7. Similar findings were observed for PP/PALF composites.

Ghazali et al. [72] investigated the effect of PALF fibers content, their type and length on the properties of biodegradable composites. Both the tensile strength and the tensile modulus of the PALF-reinforced biodegradable polymers improved significantly as a function of PALF content (10-50 wt\%). However, large aggregates formed at $50 \mathrm{wt} \%$ of PALF fibers caused a significant reduction

- Flexural strength, $\mathrm{MPa}$

- Flexural modulus, GPa

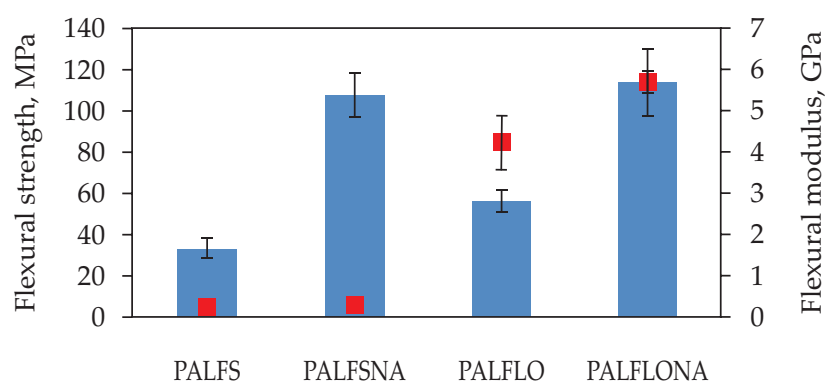

Fig. 9. Flexural properties of PLA/PALF composites 
T a b l e 7. Flexural properties of PLA and PP composites reinforced with short and long PALF fibers

\begin{tabular}{|c|c|c|c|c|}
\hline Fiber type & Fiber length, $\mu \mathrm{m}$ & Composite & Flexural strength, $\mathrm{MPa}$ & Flexural modulus, GPa \\
\hline \multirow{2}{*}{ Short } & \multirow{2}{*}{30} & PLA/PALF & 34 & 2.2 \\
\hline & & PP/PALF & 35 & 2.6 \\
\hline \multirow{2}{*}{ Long } & \multirow{2}{*}{100} & PLA/PALF & 44 & 3.2 \\
\hline & & PP /PALF & 68 & 1.9 \\
\hline
\end{tabular}

in elongation at break and increased brittleness. Similar dependencies were observed by Kaewpirom et al. [28].

\section{HYBRID PLA/STARCH/PALF COMPOSITES}

Starch is a polysaccharide polymer obtained from plants and has been used in variety of applications owing to its natural abundance, nontoxicity, low cost, renewability, biodegradability, and compostability [73]. Starch exhibit hydrophilic properties and strong intermolecular associations via hydrogen bonding formed by the hydroxyl groups on the surface [74]. Native starch can be easily transformed into thermoplastic starch (TPS) with the use of water and glycerol as plasticizers [75] under temperature and high shear forces [73]. TPS helps to reduce the cost of the finished product, and also provides partial biodegradability of thermoplastic polymers. The TPS/polymer blends can support microbial growth and tend to decrease tensile strength upon environmental exposure. Thermoplastic starch is considered to be an alternative to synthetic polymers but suffers from low strength, high water sensitivity, low thermal stability, and starch retrogradation during storage. Therefore, it is blended with other polymers and reinforced with fibers. Cellulose fiber-reinforced TPS showed increased tensile strength due to the good compatibility of similar chemical structures [76]. Also, an improvement in water resistance was achieved due to the highly crystalline hydrophobic character of the cellulose fibers in comparison with the hydrophilic starch [77]. TPS has poor mechanical properties and high water absorption, which limits its use. Blending TPS with other polymers is a simple, quick, and cheap method to overcome those drawbacks. However, PLA and TPS are thermodynamically immiscible and to improve interfacial adhesion and increase mechanical properties it is necessary to use a compatibilizer such as maleic anhydride, methylenediphenyl diisocyanate etc. or reinforce with natural fibers. Many studies have been done to investigate the mechanical properties of hybrid PLA/PALF/TPS biocomposites [62, 63, 73, 74, 78-82]. Smitthipong et al. [74] investigated the effect of PALF-reinforced TPS on the mechanical properties of PLA. The PALF content of TPS varied from 2 to $10 \mathrm{wt} \%$. TPS showed flexible behavior due to high elongation, low Young's modulus and low tensile strength. The addition (2-8 wt\%) of PALF to the TPS increased Young's modulus and tensile strength, but decreased elongation, indicating higher TPS stiffness. However, when the PALF content increased to $10 \mathrm{wt} \%$ a significant reduction in tensile strength was observed, which can be explained by the limited fibers volume in the TPS matrix. These results are in accordance with elongation at break. It can be seen in Figure 10 that the optimal concentration of PALF in TPS giving the highest tensile strength is $8 \mathrm{wt} \%$. Therefore, TPS reinforced with $8 \mathrm{wt} \%$ PALF was melt blended with PLA [74]. The tensile strength of the TPS/PLA composites decreased with increasing starch content, as shown in Figure 11. It should be noted that the role of starch is to reduce costs and accelerate degradation under composting conditions. Interestingly, when PALF-reinforced TPS was added to PLA, the tensile strength of the composite was higher compared to TPS/PLA at a given TPS content. Up to $80 \mathrm{wt} \%$ PALF-reinforced TPS content, the tensile strength of the TPS/PALF/PLA composite practically did not change, while the elongation at break decreased. This means that above $60 \mathrm{wt} \%$ of TPS, the dispersed phase of TPS changes to the continuous one. The addition of PALF which acts as a reinforcement resulted in a lower elongation at break compared to TPS/PLA.

It is well known that the higher the fiber content, the greater the strength and stiffness of the composite [6]. Selamat et al. [83] investigated the effect of short pineapple leaf fiber content $(50,60$ and $70 \mathrm{wt} \%)$ on the flexural properties of starch differing in particles size (75, 100 and $250 \mu \mathrm{m})$. It was found that, irrespective of the PALF content, the flexural strength decreased with the increase of the starch particle size. On the other hand, for the same starch particle size, the flexural strength of the

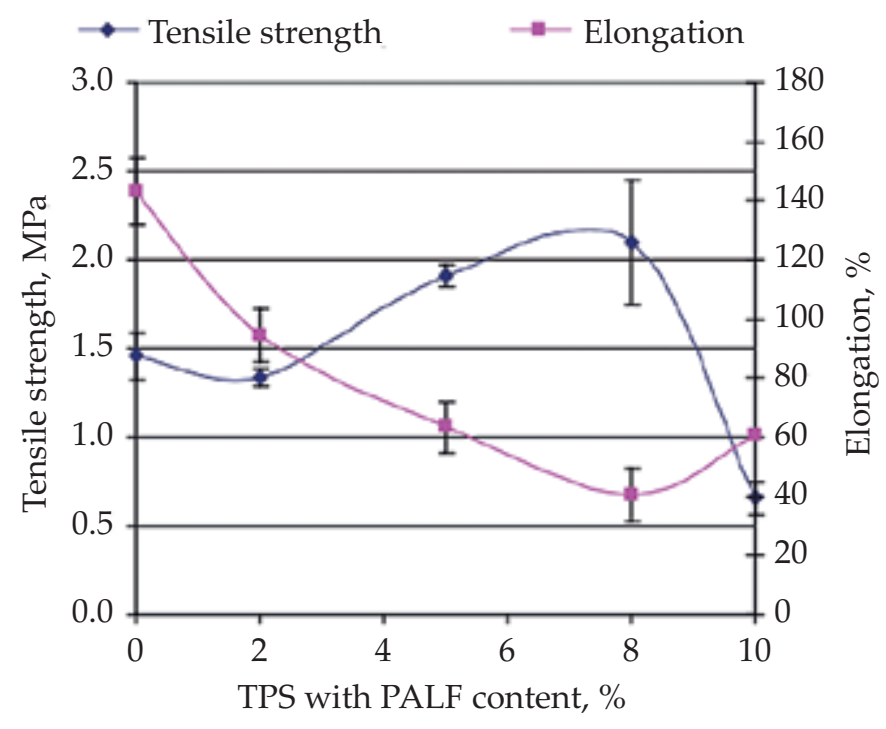

Fig. 10. Tensile properties of PALF-reinforced TPS differing in PALF content 


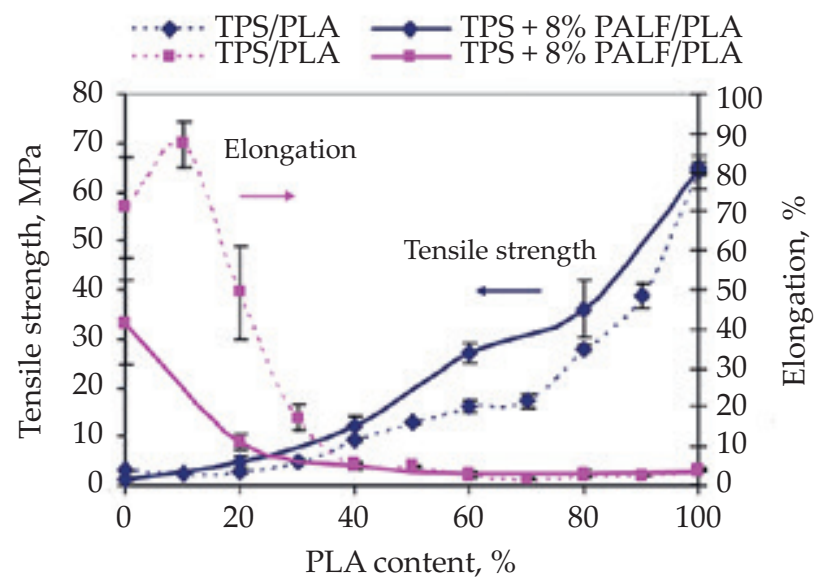

Fig. 11. Tensile properties of TPS/PLA blends and PLA/PALF/ TPS composites differing in PLA content

composite increased with increasing PALF content. For example, in the case of starch with a particle size of 75 $\mu \mathrm{m}$, the flexural strength increased from $8 \mathrm{MPa}(50 \mathrm{wt} \%$ PALF) to about $15 \mathrm{MPa}$ (70 wt\% PALF). Similar results were obtained by Selamat et al. [83] for starch reinforced with PALF short fibers of different length $(2,4$ and $6 \mathrm{~mm})$. Regardless of the fibers type and polymer matrix, these studies also highlight the significant influence of the matrix particle size. The smaller the size of the polymer matrix particles, the better the mechanical properties of the composite. This is due to the ability of the thermoplastic polymer matrix to melt rapidly under heat during pressing, which keeps the matrix firmly attached to the fiber, resulting in improved mechanical properties [22]. The smaller starch particle size will contribute to a much better surface compared to bigger particles. In the case of the composite obtained from starch with a particle size of $75 \mu \mathrm{m}$, good adhesion was observed between the chopped PALF and starch with a clean surface and minor presence of impurities compared to the composites obtained from starch with particle sizes of $100 \mu \mathrm{m}$ and $250 \mu \mathrm{m}$. This shows that the starch with the smallest particle size mixes more easily with the chopped PALF and melts evenly, creating a stronger bond between the fiber and the matrix, which has a positive effect on the mechanical properties of the composite [84].

\section{POTENTIAL APPLICATIONS OF PLA/PALF COMPOSITES}

PLA/PALF composites have enormous potential applications due to their similar properties to conventional composites and their ecological and economic benefits. Moreover, PALF can replace glass fiber (GF), which is harmful to the human health and environment. GF does not degrade, which leads to increased environmental pollution. Mechanical and physical properties of PALFreinforced biocomposites are similar to kenaf-reinforced biocomposites. PLA/PALF biocomposites can be used as more environmentally friendly products in packaging and automotive industries. Other uses are textiles, sporting goods, suitcases, furniture, mats etc. Surface-modified PALF fibers can be used to make machine parts such as webbing cords, conveyor belt cords, transmission fabrics, airbag tying cords, and some industrial fabrics [85]. PALF is very good for carpet production due to its ability to chemical treatment, dyeing and aesthetic appearance of the fabric. PALF may be suitable for various other applications such as cosmetics, medicine, and biopolymer coating [86]. Pineapple leaf fiber is one of the natural fibers with the highest cellulose content (nearly $80 \%$ ). Its density is similar to that of other natural fibers. Moreover, the Young's modulus and tensile strength are higher compared to the other natural fibers. These properties are suitable also for building and construction materials, automotive components and furniture. In Malaysia, pineapple leaf fibers have been used recently in the paper industry [87]. PALF is widely used in the textile sector as well as in articles of daily use. It is clear from this review that the thermal, electrical and dynamic properties of PALF-reinforced composites have not been the subject of extensive research yet. Until now, PALF has been used as a reinforcement for PLA, PP, HIPS and unsaturated polyester resins, therefore it is necessary to study its behavior with other resins, also in relation to the produced biocomposites and hybrid composites. Further research will significantly expand the current applications of pineapple leaf fibers.

\section{CONCLUSIONS}

This review focuses on research into the effects of PALF as reinforcement on the mechanical properties of composites over the past 10 years. Various effects have been investigated including fiber loading, fiber type, fiber size and chemical treatment. PLA/natural fibers composites can be used as an alternative to non-degradable thermoplastic packaging. In selecting a good polymer matrixfiber composite system, good adhesion between the biodegradable matrix and the fibers is extremely important to obtain the desired properties. Pineapple crop waste, such as PALF fibers, is available in large quantities in Malaysia and can be sourced from Malaysian oil palm fields, then chopped and milled into fine fibers with an accuracy of a few to a hundred micrometers. It was shown that chemically and physically treated PALF could reduce brittleness of PLA on the one hand and increase the stiffness on the other. Moreover, elongation at break and impact strength increased with increasing fiber loading. Adding an appropriate amount of other biopolymers to PLA, e.g. thermoplastic starch can change the mechanical properties of the composite and accelerate its biodegradation without the need to use high temperature and high humidity as in the case of PLA. PLA/PALF composites have specific mechanical properties and the limitations of each hybrid composite can be further improved by changing the composition of the added agricultural waste and the use of processing aids. 
Further studies may be focused on mechanical and impact properties of composites under exposure to various degrading agents such as water (hydrolytic degradation), enzyme soil (biodegradation) and oxophotodegradation (oxo and photo degradation). Dissolution in water in real river and oceanic environment can also be recommended.

\section{ACKNOWLEDGEMENT}

The authors wish to thank Malaysia Ministry of Education for providing funds to cover this studies and research through PRGS grant (600-RMC/PRGS 5/3 (021/2019) and Universiti Teknologi MARA, (UiTM) Shah Alam, Malaysia for supporting this research.

\section{REFERENCES}

[1] Munawar R.F., Jamil N.H., Shahril M.K. et al.: Applied Mechanics and Materials 2015, 761,520.

https://doi.org/10.4028/w ww.scientific.net/ AMM.761.520

[2] Macedo J. R. N., Rosa D.S.: Key Engineering Materials 2016, 668, 54 .

https://doi.org/10.4028/www.scientific.net/ KEM.668.54

[3] Siakeng R., Jawaid M., Ariffin H. et al.: Polymer Composites 2019, 40, 446.

https://doi.org/10.1002/pc.24747

[4] Oksman K., Skrifvars M., Selin J.F.: Composites Science Technology 2003, 63, 1317. https://doi.org/10.1016/S0266-3538(03)00103-9

[5] Getme A.S., Patel B.: Materials Today Proceedings 2019, 26, 2116. https://doi.org/10.1016/j.matpr.2020.02.457

[6] Todkar S.S., Patil S. A.: Composites Part B Engineering 2019, 174, 106927.

https://doi.org/10.1016/j.compositesb.2019.106927

[7] Farah S., Anderson D.G., Langer R.: Advance Drug Delivery Reviews 2016, 107, 367.

http://doi.org/10.1016/j.addr.2016.06.012

[8] Shogren R.L., Doane W.M., Garlotta D. et al.: Polymer Degradation and Stability 2003, 79, 405. https://doi.org/10.1016/S0141-3910(02)00356-7

[9] Stopper A., Okuda J., Kol M.: Macromolecules 2012, 45, 698. https://doi.org/10.1021/ma2023364

[10] Pholharn D., Srithep Y., and Morris J.: IOP Conference Series: Materials Science and Engineering 2017, 213, 1. http://doi.org/10.1088/1757-899X/213/1/012022

[11] Hassan A., Balakrishnan H., Akbari A.: Advanced Structure Materials 2013, 18, 361. https://doi.org/10.1007/978-3-642-20940-6_11,

[12] Saidi M.A., Gorin A., Heng S.K. et al.: Materials Today Proceedngs 2017, 4, 3150. https://doi.org/10.1016/j.matpr.2017.02.199

[13] Rasal R.M., Janorkar A.V., Hirt D.E.: Progress Polymer Science 2010, 35, 338. https://doi.org/10.1016/j.progpolymsci.2009.12.003

[14] Saba N., Jawaid M., Sultan M.T.H.: Lignocellulosic Fibre and Biomass-Based Composite Materials: Processing, Properties and Applications 2017, 1, 95.

http://doi.org/10.1016/B978-0-08-100959-8.00006-8

[15] Auras R., Harte B., Selke S.: Macromolecule Bioscience 2004, 4, 835 .

http://doi.org/10.1002/mabi.200400043

[16] Janorkar A.V., Metters A.T., Hirt D.E.: Macromolecule 2004, 37, 9151.

https://doi.org/10.1021/ma049056u

[17] Tokiwa Y., Calabia B.P.: Applied Microbiology Biotechnology 2006, 72, 244. http://doi.org/10.1007/s00253-006-0488-1

[18] Putri D.N., Perdani M.S., Arbianti R. et al.: Energy Reports 2020, 6, 221.

https://doi.org/10.1016/j.egyr.2019.08.048

[19] Burg K.J.L., Holder W.D., Culberson C.R. et al.: Journal of Biomaterials Science Polymer Edition 1999, 10, 147. http://doi.org/10.1163/156856299X00108

[20] Koh J.J., Zhang X., He C.: International Journal of Biological Macromolecules 2018, 109, 99. https://doi.org/10.1016/j.ijbiomac.2017.12.048/

[21] Sangeetha V.H., Deka H., Varghese T.O. et al.: Polymer Composites 2018, 39, 81.

https://doi.org/10.1002/pc.23906

[22] Ilyas R.A., Sapuan S.M., Kadier A. et al.: Advance Processing, Properties, and Applications of Starch and Other Bio-Based Polymers 2020, 111. https://doi.org/10.1016/B978-0-12-819661-8.00008-1

[23] Zaaba N.F., Jaafar M.: Polymer Engineering and Science 2020, 60, 2061. https://doi.org/10.1002/pen.25511

[24] Doshi Y., Dhruve H.: Journal of the Textile Association $2021,20,218$.

https://www.researchgate.net/publication/352451831

[25] Kumar R., Obrai S., Sharma A.: Pelagia Research Library 2011, 2, 219.

www.pelagiaresearchlibrary.com

[26] Begum K., Islam M.A.: Research Journal of Engineering Sciences 2013, 2(3), 46. www.isca.in

[27] Yashas G. T. G., Sanjay M.R., Parameswaranpillai J. et al.: Frontiers in Materials 2019, 6, 226. https://doi.org/10.3389/fmats.2019.00226

[28] Kaewpirom S., Worrarat C., Fibers and Polymers 2014, $15,1469$. https://doi.org/10.1007/s12221-014-1469-0

[29] Huda M.S., Drzal L.T., Mohanty A.K. et al.: Composite Interfaces 2008, 15, 169. https://doi.org/10.1163/156855408783810920

[30] Devi L.U., Bhagawan S.S., and Thomas S.: Journal of Applied Polymer Science 1997, 64, 1739.

h t t p s : / / o i . or g / 10.1002 / ( S I C I ) 1097 4628(19970531)64:9\%3C1739::AID-APP10\%3E3.0.CO;2-T

[31] Khalil H.P.S.A., Jawaid M., Hassan A. et al.: Composites and Their Applications 2012, 8,187 
http://doi.org/10.5772/48235

[32] Liu W., Drzal L.T., Mohanty A.K. et al.:, Composites Part B Engineering 2007, 38, 352.

https://doi.org/10.1016/j.compositesb.2006.05.003

[33] Asim M., Abdan K., Jawaid M. et al.: International Journal of Polymer Science 2015, 2015,1. http://doi.org/10.1155/2015/950567

[34] Yahya S.A.B., Yusof Y., Advanced Materials Research 2013, 701, 430.

http://doi.org/10.4028/www.scientific.net/ AMR.701.430

[35] Bhaduri S.K., Sen S.K.: Carbohydrate Research 1983, 121, 211. http://doi.org/10.1016/0008-6215(83)84018-X

[36] Saha S.C., Ray P.K., Pandey S.N. et al.: Journal of Applied Polymer Science 1991, 42, 2767. https://doi.org/10.1002/app.1991.070421015

[37] Mohanty A.K., Misra M., Hinrichsen G.: Macromolecular Materials and Engineering 2000, 276/277, 1.

h t t p : / / d o i.org / 10.1002 / ( S I C I ) 1439 2054(20000301)276:1\%3C1::AID-MAME1\%3E3.0.CO;2-W

[38] Reddy N., Yang Y.: Trends in Biotechnology 2005, 23, 22. https://doi.org/10.1016/j.tibtech.2004.11.002

[39] Abdul Khalil H.P.S., Siti Alwani M., Mohd Omar A.K.: BioResources 2006, 1, 220.

[40] Idicula M., Boudenne A., Umadevi L. et al.: Composites Science and Technology 2006, 66, 2719. https://doi.org/10.1016/j.compscitech.2006.03.007

[41] Satyanarayana K., Guimaraes J., Wypych F.: Composites Part A: Applied Science and Manufacturing 2007, 38, 1694. https://doi.org/10.1016/j.compositesa.2007.02.006

[42] Siregar J. P., Sapuan S. M., Rahman M. Z. A. et al::Advance Composites Letter 2008, 18, 25.

[43] Chattopadhyay S.K., Singh S., Paramanik N. et al.: Journal of Applied Science Polymer 2011, 121, 2226. http://dx.doi.org/10.1002/app.33828

[44] Zhou Y., Fan M., Chen L.: Composites Part B: Engineering 2016, 101, 31. http://doi.org/10.1016/j.compositesb.2016.06.055.

[45] Ramli S.N.R., Fadzullah S.H.S.M., Mustafa Z.: Jurnal Teknologi 2016, 2, 111. http://dx.doi.org/10.11113/jt.v79.11293

[46] George J., Joseph K., Bhagawan S.S. et al.: Materials Letters 1993, 18,163.

https://doi.org/10.1016/0167-577X(93)90119-I

[47] Luo S., Netravali N.: Polymer Composites 1999, 20, 367. https://doi.org/10.1002/pc.10363

[48] Arib R.M.N., Sapuan S.M., Ahmad M.M.H.M. et al.: Materials and Design 2006, 27, 391. https://doi.org/10.1016/j.matdes.2004.11.009

[49] Mohamed A.R., Sapuan S.M., Shahjahan M. et al.: International Journal of food, agriculture and environment 2009, 7, 235.

[50] Ho M.P., Wang H., Lee J.H. et al.: Composites: Part B Engineering 2012, 43, 3549.
[51] Saba N., Paridah M. T., Jawaid M.: Construction and Building Materials 2015, 76, 87. http://dx.doi.org/10.1016/j.conbuildmat.2014.11.043

[52] Moshiul Alam A.K.M., Beg M., Reddy Prasad D.M. et al.: Composites Part A: Applied Science and Manufacturing 2012, 43, 1921.

http://doi.org/10.1016/j.compositesa.2012.06.012

[53] Joseph S., Joseph K., Thomas S.: International Journal Polymeric Materials and Polymeric Biomaterials 2006, $55,925$. https://doi.org/10.1080/00914030600550505

[54] Huda M.S., Drzal L.T., Misra M. et al.: Journal of Applied Polymer Science 2016, 102, 4856. https://doi.org/10.1002/app.24829

[55] Rashid B., Leman Z., Jawaid M. et al.: Bioresources 2017, 12(1), 1447.

https://doi.org/10.15376/biores.12.1.1447-1462

[56] Ochi S.: Mechanics of Materials 2008, 40, 446. https://doi.org/10.1016/j.mechmat.2007.10.006

[57] Manalo A.C., Wani E., Zulkarnain N.A. et al.: Composites Part B: Engineering 2015, 80, 73. https://doi.org/ 10.1016/j.compositesb.2015.05.033

[58] Nagu K.S., Yoganandam K., Mohanavel V. et al.: Materials Today : Proceedings 2020, 33, 3061. https://doi.org/10.1016/j.matpr.2020.03.511

[59] Islam M.S., Pickering K.L., Foreman N.J.: Composites Part A :Applied Science and Manufacturing 2010,41, 596. https://doi.org/10.1016/j.compositesa.2010.01.006

[60] Mylsamy K., Rajendran I.: Materials and Design 2011, 32, 3076. https://doi.org/ 10.1016/j.matdes.2010.12.051

[61] Srisuwan S., Prasoetsopha N., Suppakarn N. et al.: Energy Procedia 2014, 56, 19. https:// doi.org/10.1016/j.egypro.2014.07.127

[62] Aji I.S., Zainudin E.S., Khalina A.et al.: Key Engineering Materials 2011, 471, 680.

https://doi.org/10.4028/www.scientific.net/KEM.471472.680

[63] Mohamed M.M.F., Mohamed R.: Advance Materials Research 2015, 1113, 1222.

https://doi.org/10.4028/www.scientific.net/ AMR.1113.122

[64] Tiesong L., Peigang H., Defu L.: Bulletin of Materials Science 2009, 32, 77. https://doi.org/10.1007/s12034-009-0011-2

[65] Rezaei F., Yunus R., Ibrahim N.A.: Materials and Design 2009, 30, 260.

https://doi.org/10.1016/j.matdes.2008.05.005

[66] Capela C., Oliveira S.E., Pestana J. et al.: Procedia Structural Integrity 2017, 5, 539. https://doi.org/10.1016/j.prostr.2017.07.159

[67] Shibata M., Ozawa K., Teramoto N. et al.: Macromolecular Materials and Engineering 2003, 288, 35. https://doi.org/10.1002/mame.200290031

[68] Felix J.M., Gatenholm P.: Journal of Materials Science 1994, 29, 3043. 
https://doi.org/10.1007/BF01117618

[69] Siregar J. P., Sapuan S.M., Rahman M.Z.A. et al.: Advance Composites Letters 2009, 18, 25. https://doi.org/10.1177/096369350901800104

[70] Tawakkal I.S.M.A., Talib R.A., Abdan K., Ling Ch.N.: BioResources 2012, 2(7), 1643.

https://doi.org/10.15376/biores.7.2.1643-1655

[71] Md Fadzullah S.H.S., Mustafa Z., Ramli S.N.R. et al.: Key Engineering Materials 2016, 694, 18.

http://dx.doi.org/10.4028/www.scientific.net/ KEM.694.18

[72] Beg H., Akindoyo J.O., Ghazali S. et al.: International Journal of Chemical, Nuclear, Materials and Metallurgical Engineering 2015, 9,1. https://doi.org/10.5281/zenodo.1099244

[73] Raghu N., Kale A., Raj A. et al.: Journal of Applied Polymer Science 2018, 135, 1. https://doi.org/10.1002/app.46118

[74] Smitthipong W., Tantatherdtam R., Chollakup R.: Journal of Thermoplastic Composite Materials 2015, 28, 717. https://doi.org/10.1177/0892705713489701

[75] Akrami M., Ghasemi I., Azizi H. et al.: Carbohydrate Polymers 2016, 144, 254. http://dx.doi.org/10.1016/j.carbpol.2016.02.035

[76] Wollerdorfer M., Bader H.: Industrial Crops and Products 1998, 8, 105. https://doi.org/10.1016/S0926-6690(97)10015-2

[77] Dufresne A., Dupeyre D., Vignon M.R.: StarchCellulose Micrifibril Composites 1999, 76(14), 2080. h t t p://dx.doi.org / 10.1002 / ( S IC I ) 1097 4628(20000628)76:143.0.CO;2-U

[78] Hapizi N., Mohamed R.: IOP Conference Series Materials Science and Engineering 2021, 1091, 012077.
https://doi.org/10.1088/1757-899X/1091/1/012077

[79] Abd Aziz N.Z., Mohamed R.: Advance Materials Research 2013, 748, 201.

https://doi.org/10.4028/www.scientific.net/ AMR.748.201

[80] Zuhaira A.A.N., Rahmah M..: Advance Materials Research,2013, 795, 286.

https://doi.org/10.4028/www.scientific.net/ AMR.795.286

[81] Rahmah M., Zuhaira N., Aziz A. et al.: International Journal of Industrial and Manufacturing Engineering, 2015, 9, 364 https://doi.org/10.5281/zenodo.1100571

[82] Muizz M., Mohamed F., Mohamed R.et al:: Proceedings of Postgraduate Conference on Global Green Issues (Go Green) 2007, 748, 201

http://dx.doi.org/10.4028/www.scientific.net/ AMR.748.201

[83] Selamat M.Z., Syazwan M., Tahir Z. et al.: MATEC Web of Conferences 2018, 04008, 1. https://doi.org/10.1051/matecconf/201815004008

[84] Luo S., Netravali A.N. et al.: Polymer Composites 1999, 20, 367. https://doi.org/10.1002/pc.10363

[85] Basu P.R.K.A., Chellamani K.P.: Asian Textile Journal 2003, 12, 94.

[86] Geethamma V.G., Mathew K.T., Lakshminarayanan R. et al:: Polymer 1998, 39, 1483. https://doi.org/10.1016/S0032-3861(97)00422-9

[87] Yusof Y., Ahmad M. R., Wahab S. et al.: Advance Materials Research 2012, 383-390, 3382. https://doi.org/10.4028/www.scientific.net/AMR.383390.3382

Received 3 X 2021.

\section{(3) Polimery - czasopismo naukowo-techniczne

